Supplement of

\title{
Chemical characteristics of cloud water and the impacts on aerosol properties at a subtropical mountain site in Hong Kong SAR
}

Tao Li et al.

Correspondence to: Zhe Wang (z.wang@ust.hk)

The copyright of individual parts of the supplement might differ from the CC BY 4.0 License. 
Table S1. Comparison of glyoxal and methylglyoxal in cloud water $[\mu \mathrm{M}]$ and their gas-phase precursors [ppb] as well as pollutants concentrations $[\mathrm{ppb}]$ at Mt. TMS and other sites.

\begin{tabular}{|c|c|c|c|c|c|c|c|c|c|}
\hline & Glyoxal & $\begin{array}{l}\text { Methyl } \\
\text { glyoxal }\end{array}$ & Isoprene & Benzene & Toluene & Xylene & $\mathrm{NO}_{\mathrm{x}}$ & $\mathrm{O}_{3}$ & Ref \\
\hline Mt. TMS & 6.7 & 19.1 & 0.16 & 0.5 & 2.3 & \multirow[t]{5}{*}{0.9} & 3 & 31 & \multirow{5}{*}{$\begin{array}{l}\text { this study } \\
\text { (Ervens et } \\
\text { al., 2013) } \\
\text { (Ervens et } \\
\text { al., 2013) } \\
\text { (van } \\
\text { Pinxteren et } \\
\text { al., 2005) } \\
\text { (Deguillaum } \\
\text { e et al., } \\
\text { 2014;Barbet } \\
\text { et al., 2016) }\end{array}$} \\
\hline Whistler, Canada & $0.6-1.8$ & $0.5-7.4$ & 0.6 & 0.05 & 0.1 & & 4 & 25 & \\
\hline Davis, USA & $1.3-8.7$ & $0.1-0.9$ & 0.2 & 2 & 4 & & 20 & 70 & \\
\hline $\begin{array}{l}\text { Mt. Schmücke, } \\
\text { Germany }\end{array}$ & $0.8-11.3$ & $0.4-3.3$ & & & & & & & \\
\hline $\begin{array}{l}\text { Puy de Dôme, } \\
\text { France }\end{array}$ & $0.13-0.89$ & $0.01-0.2$ & & up to 1 & & & & & \\
\hline
\end{tabular}

\footnotetext{
${ }^{a}$ sum of observed benzene, toluene and ethylbenzene (Barbet et al., 2016)
} 
Table S2. Description of six cloud events at Mt. TMS in November 2015. Sampling time, sample number (n), liquid water content (LWC), pH values, equivalent molar ratios of chloride, potassium, calcium and magnesium to sodium and non-sea-salt sulfate (nss- $\mathrm{SO}_{4}{ }^{2-}$ ) to nitrate, formic-toacetic acid (F/A) ratio in cloud water and in the corresponding gas phase (calculated), and trace gases are included.

\begin{tabular}{|c|c|c|c|c|c|c|c|c|c|c|c|c|c|c|c|}
\hline Events & Day & $\begin{array}{l}\text { Sampling } \\
\text { duration }\end{array}$ & $\mathrm{n}$ & $\begin{array}{l}\text { LWC } \\
\left(\mathrm{g} \mathrm{m}^{-3}\right)\end{array}$ & $\mathrm{pH}$ & $\begin{array}{l}\mathrm{Cl}^{-} / \mathrm{Na}^{+} \\
\left(1.16^{*}\right)\end{array}$ & $\begin{array}{l}\mathrm{K}^{+} / \mathrm{Na}^{+} \\
(0.02 *)\end{array}$ & $\begin{array}{l}\mathrm{Ca}^{2+} / \mathrm{Na}^{+} \\
\left(0.04^{*}\right)\end{array}$ & $\begin{array}{l}\mathrm{Mg}^{2+} / \mathrm{Na}^{+} \\
\left(0.23^{*}\right)\end{array}$ & 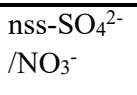 & $\begin{array}{l}\text { F/A } \\
\text { (cloud) }\end{array}$ & $\begin{array}{l}\text { F/A } \\
\left(\text { gas**) }^{*}\right)\end{array}$ & $\begin{array}{l}\mathrm{SO}_{2} \\
(\mathrm{ppb})\end{array}$ & $\begin{array}{l}\mathrm{NO}_{\mathrm{x}} \\
(\mathrm{ppb})\end{array}$ & Air mass description \\
\hline$\overline{\text { E. } 1}$ & 8 & $15: 10-17: 30$ & 1 & 0.08 & 5.5 & 2.14 & 0.41 & 5.06 & 0.47 & 1.03 & 2.3 & 0.4 & 2.7 & 12.3 & $\begin{array}{l}\text { Heavily polluted by cold front, } \\
\text { continental, altitude }<1 \mathrm{~km}\end{array}$ \\
\hline E. 2 & 9 & 03:10-15:00 & 4 & 0.18 & 3.82 & 3.11 & 0.50 & 4.15 & 0.48 & 1.38 & 1.6 & 1.2 & 1.3 & 1.9 & $\begin{array}{l}\text { Clean after cold front passage, } \\
\text { continental, }<1 \mathrm{~km}\end{array}$ \\
\hline E. 3 & 11 & $12: 20-21: 40$ & 2 & 0.21 & 3.3 & 2.46 & 0.15 & 0.58 & 0.23 & 0.91 & 1.2 & 1.5 & 1.1 & 1.6 & $\begin{array}{l}\text { Circling from sea to PRD region, } \\
\text { mixed, }<1 \mathrm{~km}\end{array}$ \\
\hline E.4 & $15-16$ & $21: 10-13: 20$ & 6 & 0.15 & 3.17 & 1.62 & 0.06 & 0.13 & 0.22 & 1.48 & 1.5 & 1.9 & 0.8 & 1.1 & $\begin{array}{l}\text { Along the southeast coast of China, } \\
\text { mixed, }<1 \mathrm{~km}\end{array}$ \\
\hline E.5 & $18-19$ & $16: 30-13: 10$ & 8 & 0.28 & 3.56 & 1.51 & 0.04 & 0.04 & 0.22 & 1.69 & 1.7 & 1.7 & 0.7 & 0.8 & $\begin{array}{l}\text { Deriving from west Pacific Ocean, } \\
\text { marine, } 1 \text { to } 1.5 \mathrm{~km}\end{array}$ \\
\hline E. 6 & $21-22$ & $12: 30-16: 00$ & 11 & 0.35 & 4.19 & 1.50 & 0.04 & 0.08 & 0.16 & 1.51 & 0.9 & 0.5 & 0.9 & 1.6 & $\begin{array}{l}\text { Deriving from west Pacific Ocean, } \\
\text { marine, }>1.5 \mathrm{~km}\end{array}$ \\
\hline
\end{tabular}

*: equivalent molar ratio of seawater.

**: refer to Sun et al. (2016) for the calculation of F/A ratio in the gas phase corresponding to the original liquid phase. $[\mathrm{F} / \mathrm{A}]_{\mathrm{M}}=\frac{\mathrm{K}_{\mathrm{H} 1}\left(\mathrm{H}^{+}+\mathrm{K}_{\mathrm{a}}\right)}{\mathrm{K}_{\mathrm{H} 2}\left(\mathrm{H}^{+}+\mathrm{K}_{\mathrm{b}}\right)}[\mathrm{F} / \mathrm{A}]_{\mathrm{C}}$, where $[\mathrm{F} / \mathrm{A}]_{\mathrm{M}}$ is the measured $\mathrm{F} / \mathrm{A}$ ratio in the liquid phase and $[\mathrm{F} / \mathrm{A}]_{\mathrm{C}}$ is the corresponding calculated $\mathrm{F} / \mathrm{A}$ ratio in the gas phase; $\mathrm{K}_{\mathrm{H} 1}=5.6 \times 10^{3} \mathrm{M}$ $\mathrm{atm}^{-1}$ and $\mathrm{K}_{\mathrm{H} 2}=8.8 \times 10^{3} \mathrm{M}$ atm $^{-1}$ are Henry constants for formic and acetic acids, respectively; $\mathrm{K}_{\mathrm{a}}=1.77 \times 10^{-4} \mathrm{~mol} \mathrm{~L}^{-1}$ and $\mathrm{K}_{\mathrm{b}}=1.76 \times 10^{-5} \mathrm{~mol}$ $\mathrm{L}^{-1}$ are the dissociation constants of formic and acetic acids, respectively. 
Table S3. Concentration ratios of formaldehyde/acetaldehyde $(\mathrm{C} 1 / \mathrm{C} 2)$ and acetaldehyde/propanal $(\mathrm{C} 2 / \mathrm{C} 3)$ in the gas phase during cloud events. The gas phase carbonyl compounds in E.1 and E.2 were NOT measured.

\begin{tabular}{lll}
\hline Event & $\mathrm{C} 1 / \mathrm{C} 2$ & $\mathrm{C} 2 / \mathrm{C} 3$ \\
\hline E.3 & $2.8 \pm 0.5$ & $6.4 \pm 1.7$ \\
E.4 & $4.5 \pm 2.8$ & $4.4 \pm 1.6$ \\
E.5 & $3.8 \pm 0.5$ & $5.8 \pm 2.6$ \\
E.6 & $3.0 \pm 0.6$ & $3.8 \pm 0.8$ \\
\hline
\end{tabular}

Table S4. Carbonyls concentrations (Mean $\pm \mathrm{SD}$ ) in cloud water and gas phase, as well as measured and theoretical partitioning fraction of carbonyls in the aqueous phase $\left(\mathrm{F}_{\mathrm{p}}\right)$. The measured carbonyls in cloud water were scaled by LWC to their air equivalent concentrations.

\begin{tabular}{lllllll}
\hline & Cloud water & Gas phase & \multicolumn{2}{c}{$\mathrm{F}_{\mathrm{p}}$} & $K_{\mathrm{H}}$ & \multirow{2}{*}{ ref } \\
\cline { 4 - 5 } & (ppbv) & $(\mathrm{ppbv})$ & Measured & Theoretical & M atm & \\
\hline Glyoxal & $(5.61 \pm 3.87) \times 10^{-2}$ & $0.05 \pm 0.01$ & $5.08 \times 10^{-1}$ & $7.48 \times 10^{-1}$ & $4.19 \times 10^{5}$ & (Ip et al., 2009) \\
Methylglyoxal & $(1.22 \pm 1.03) \times 10^{-1}$ & $0.19 \pm 0.14$ & $3.14 \times 10^{-1}$ & $2.03 \times 10^{-1}$ & $3.2 \times 10^{4}$ & (Zhou and Mopper, 1990) \\
Formaldehyde & $(6.48 \pm 4.42) \times 10^{-3}$ & $1.98 \pm 0.34$ & $3.59 \times 10^{-3}$ & $2.60 \times 10^{-2}$ & $3.24 \times 10^{3}$ & (Sander, 2015) \\
Acetaldehyde & $(2.16 \pm 1.23) \times 10^{-3}$ & $0.62 \pm 0.21$ & $3.83 \times 10^{-3}$ & $1.09 \times 10^{-4}$ & 13.17 & (Sander, 2015) \\
Acetone & $(2.38 \pm 2.10) \times 10^{-3}$ & $2.23 \pm 1.32$ & $2.01 \times 10^{-3}$ & $2.26 \times 10^{-4}$ & 27 & (Sander, 2015) \\
Propanal & $(5.05 \pm 5.90) \times 10^{-3}$ & $0.14 \pm 0.05$ & $3.24 \times 10^{-2}$ & $9.49 \times 10^{-5}$ & 9.9 & (Sander, 2015) \\
\hline
\end{tabular}




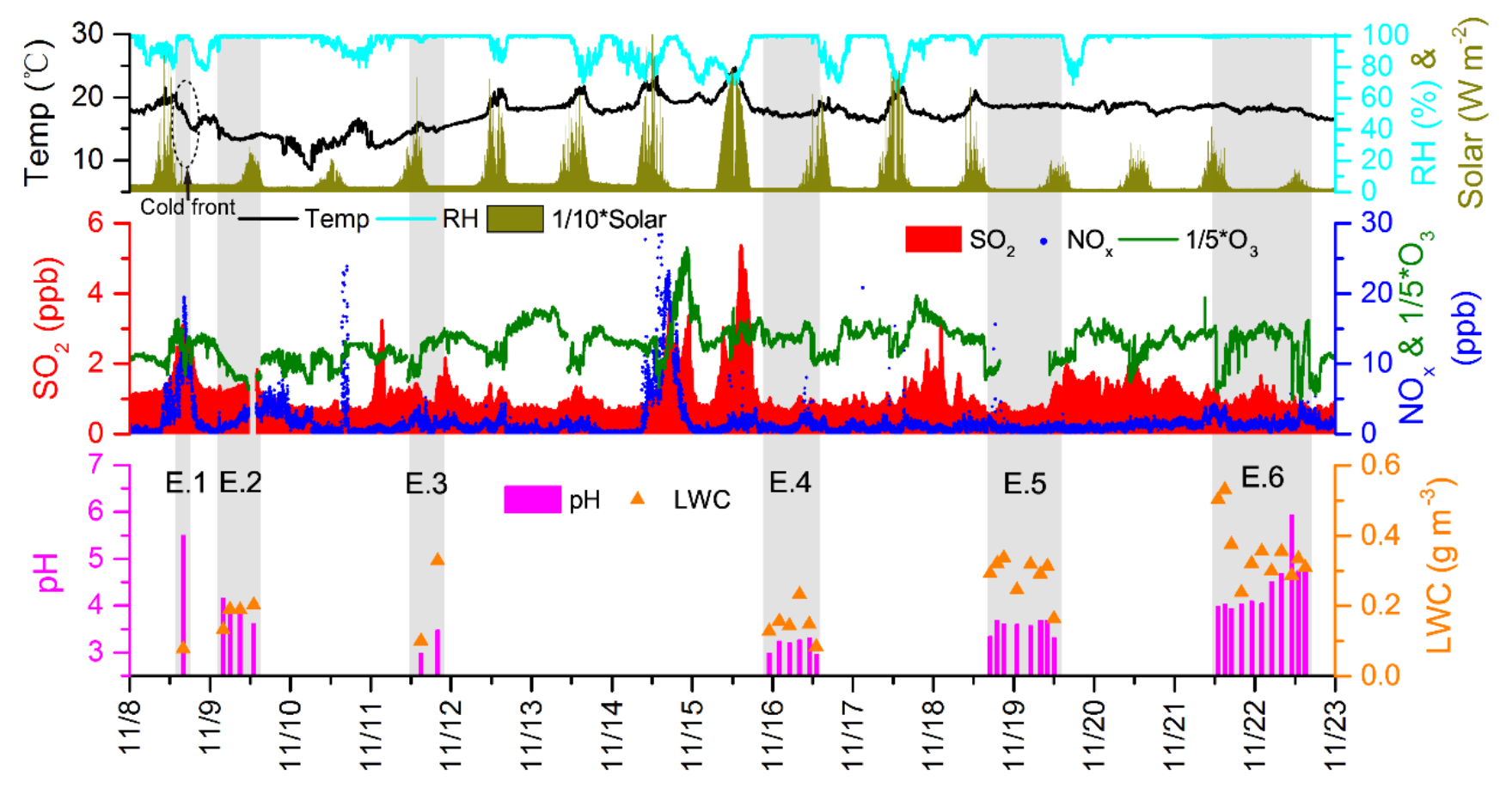

Figure S1. Time series of $\mathrm{pH}$ values and LWC of cloud water samples for six events (E.1-6) at Mt. TMS in Hong Kong in November 2016. Gray areas indicate cloud water sampling periods during the campaign. Meteorological parameters including temperature, relative humidity $(\mathrm{RH})$ and solar radiation are shown in the top panel. Trace gases $\left(\mathrm{SO}_{2}, \mathrm{NO}_{x}\right.$ and $\mathrm{O}_{3}$ ) are displayed in the middle panel. A short-time cold front passage (14:00-20:00, 8 November 2016) is labeled by dotted ellipse, which is recorded by Hong Kong observatory (www.weather.gov.hk/contente.htm). 


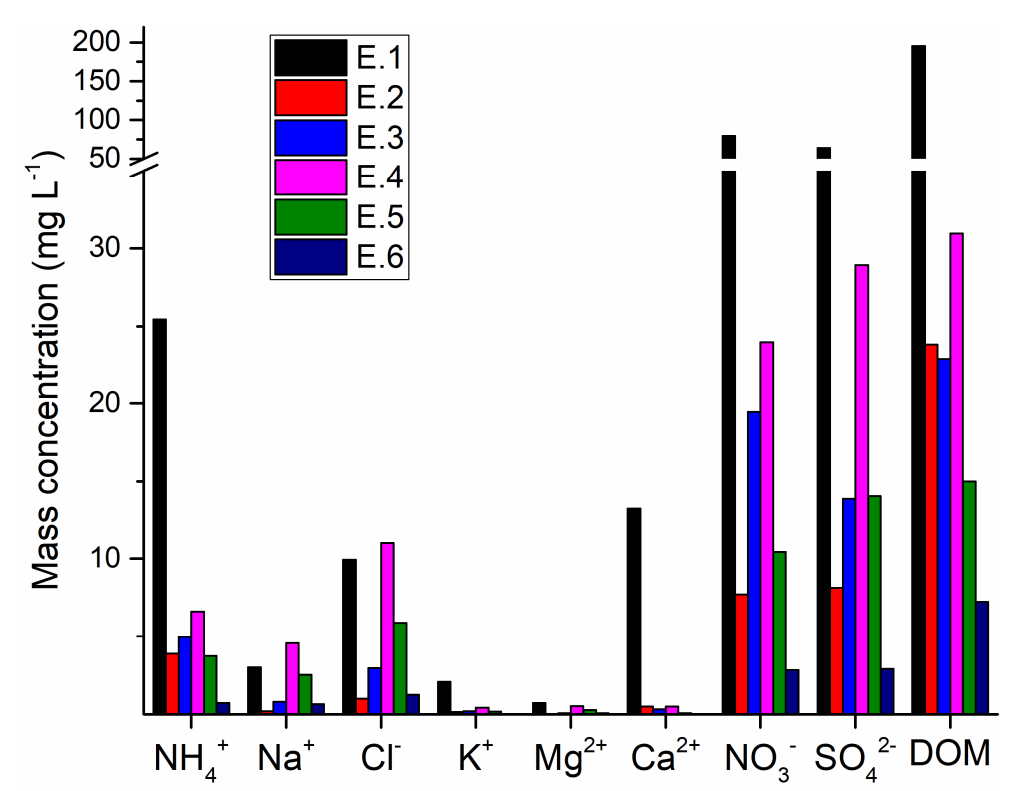

Figure S2. Absolute mass concentrations of major components in cloud water for case E.1-6.

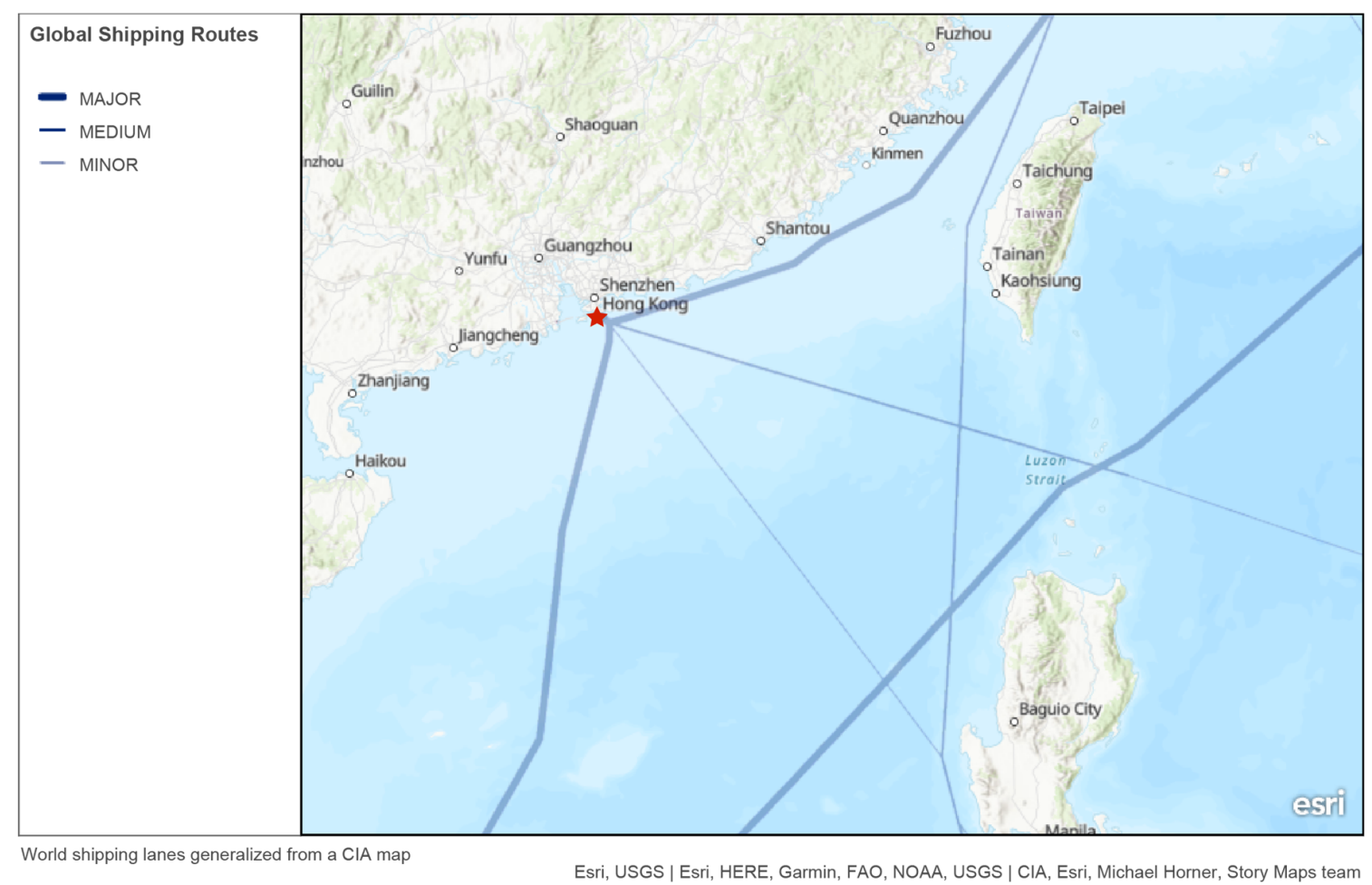

Figure S3. International shipping routes going throgh Hong Kong (red star) in the western Pacific Ocean. The map is reproduced from the ArcGIS Online map of global shipping routes (https://www.arcgis.com/home/index.html) and processed using Adobe Illustrator CS6 software. 
(a)
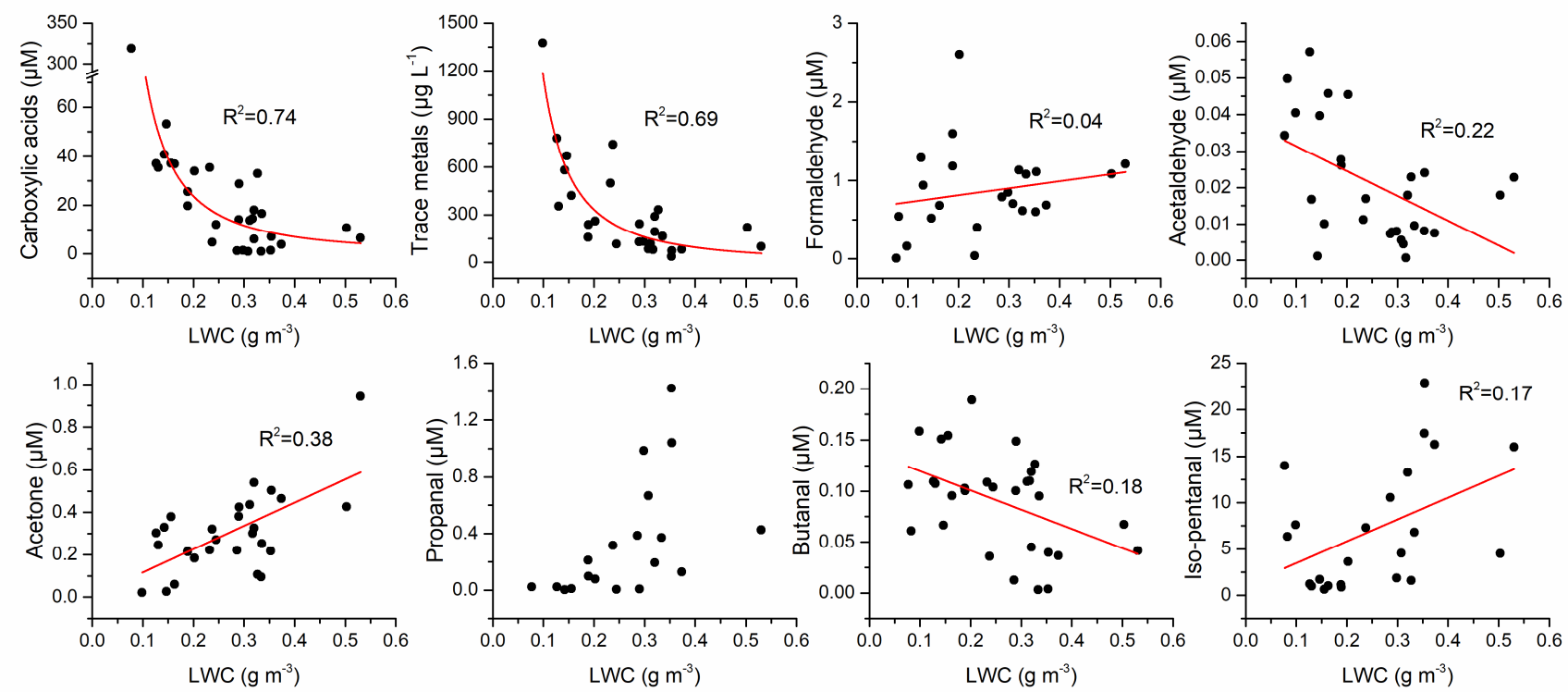

(b)
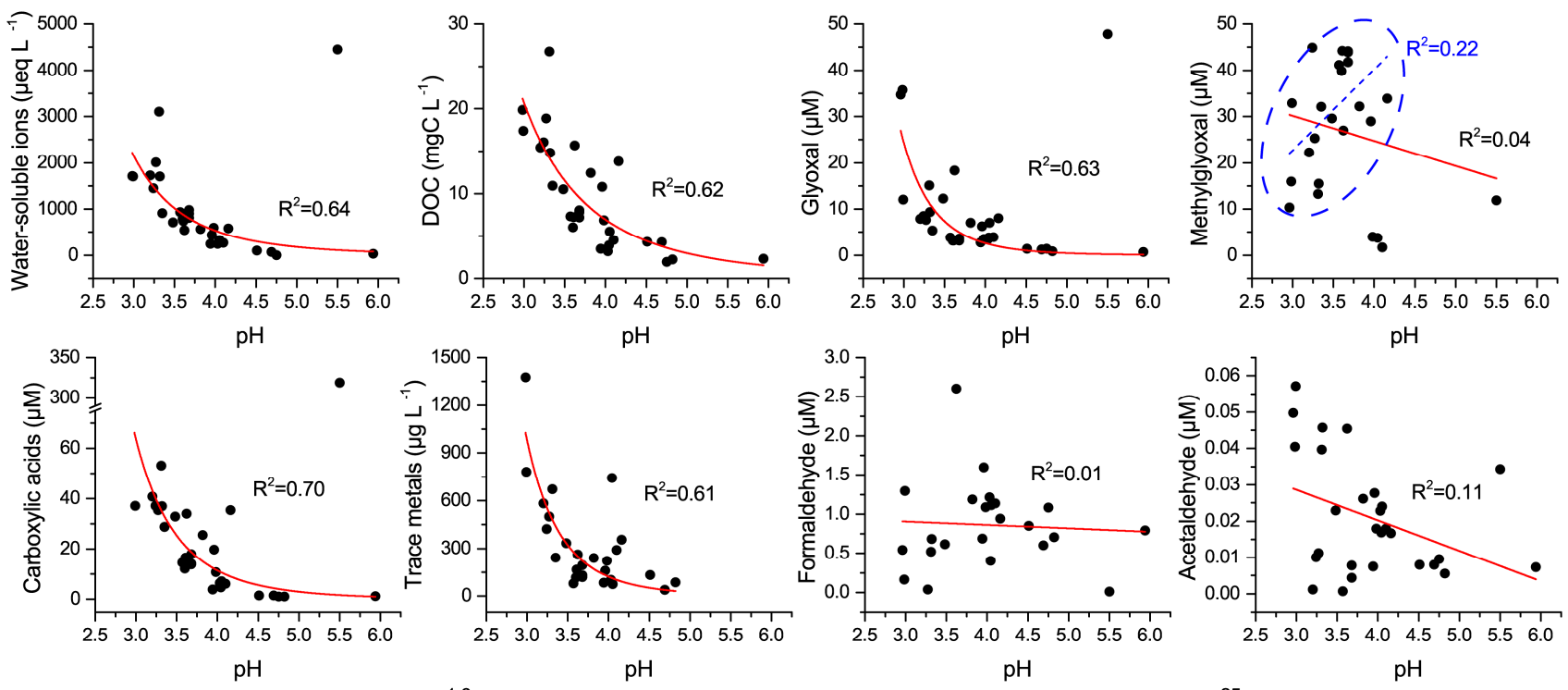

$\mathrm{pH}$

$\mathrm{pH}$
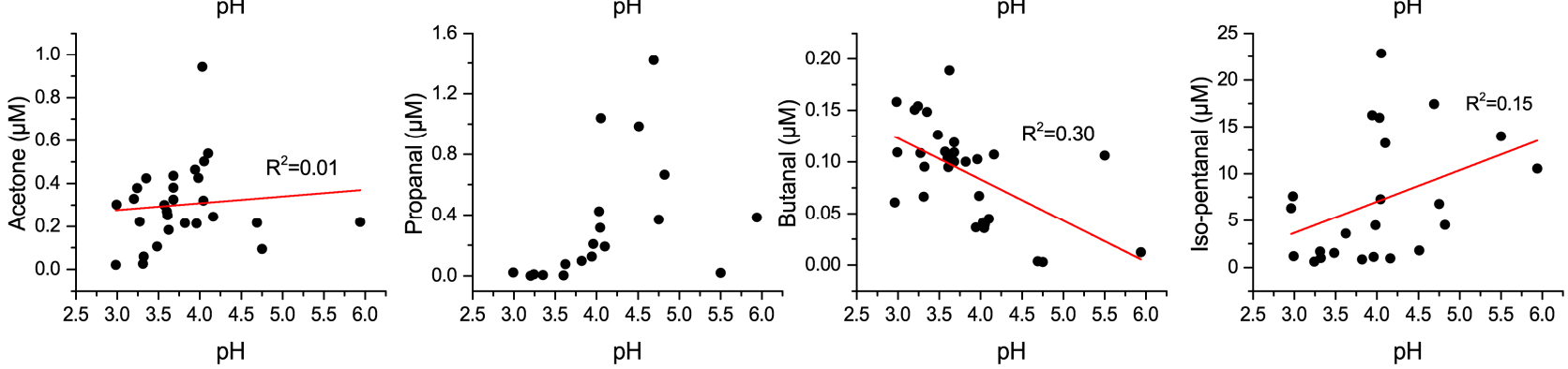

Figure S4. Relationships of water-soluble ions, DOC, carboxylic acids, trace metals and individual carbonyl compounds with (a) LWC and (b) $\mathrm{pH}$ in cloud water. 


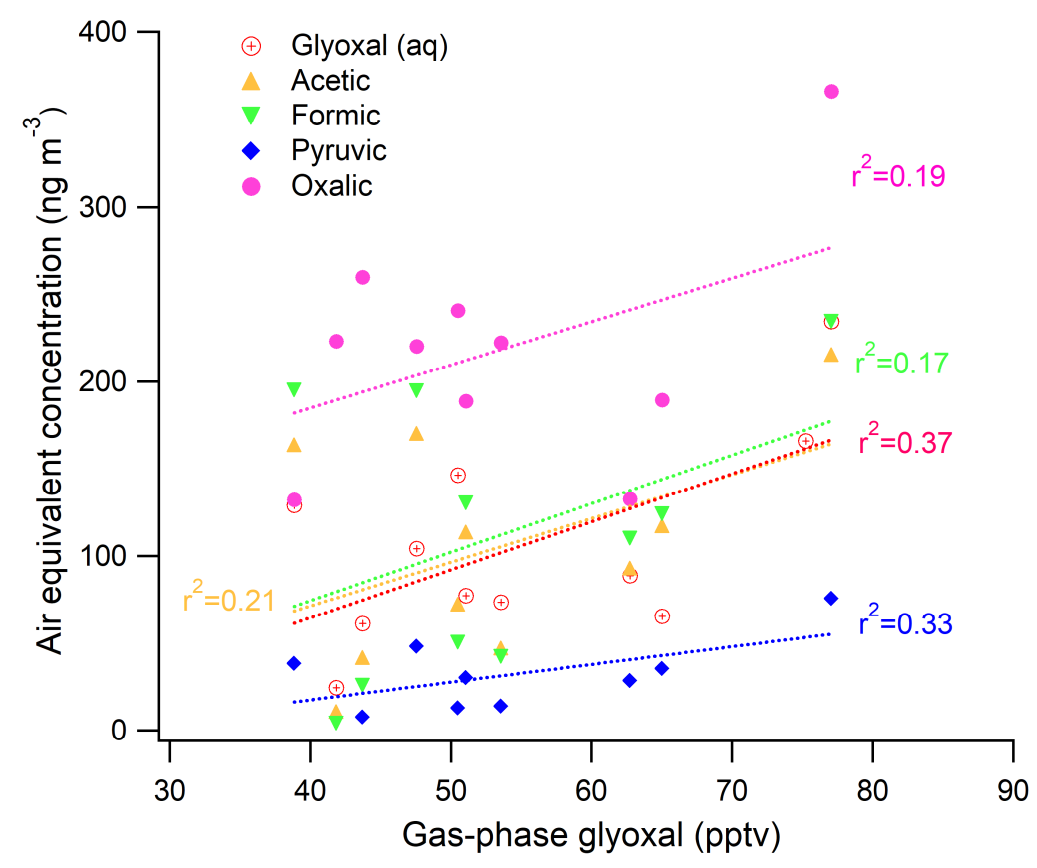

Figure S5. Relationships of the aqueous-phase glyoxal and carboxylic acids with gas-phase glyoxal. Air equivalent concentrations of aqueous phase organics were used to eliminate LWC effects.

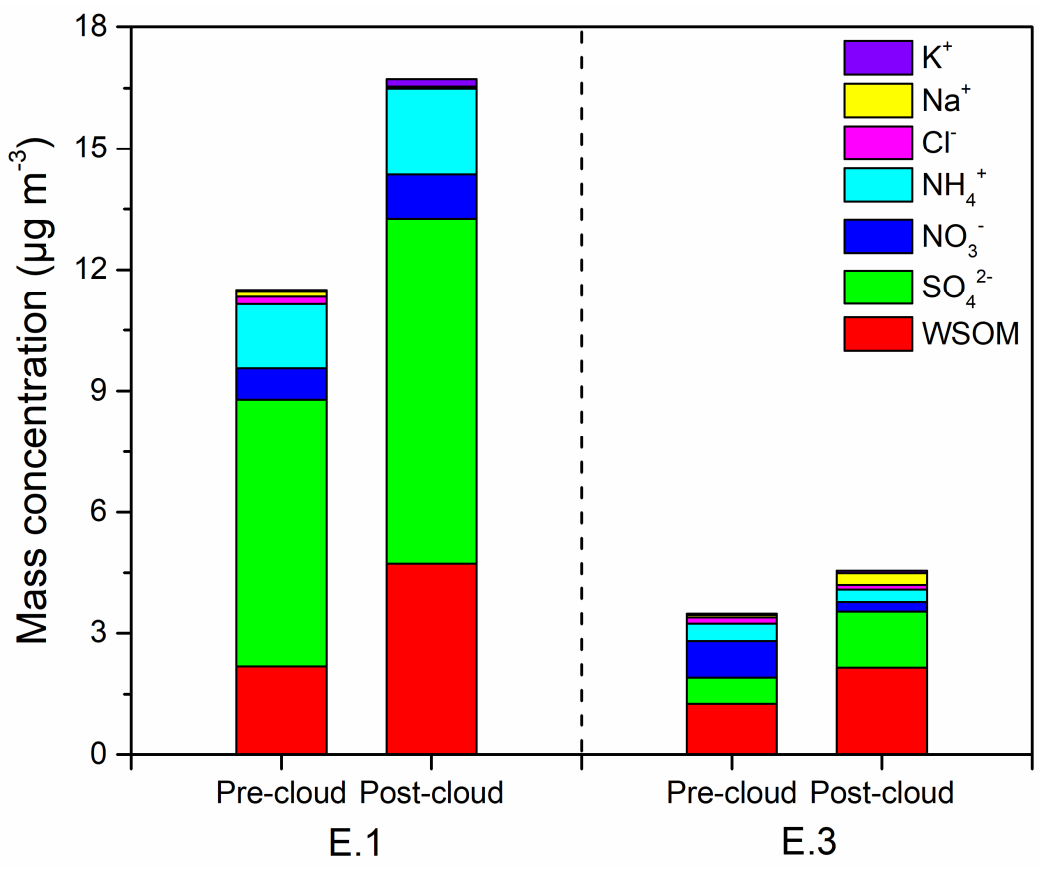

Figure S6. Absolute mass concentration of major water-soluble components in the pre-cloud and post-cloud aerosols for cloud events E.1 and E.3. 


\section{References}

Barbet, C., Deguillaume, L., Chaumerliac, N., Leriche, M., Freney, E., Colomb, A., Sellegri, K., Patryl, L., and Armand, P.: Evaluation of Aerosol Chemical Composition Simulations by the WRF-Chem Model at the Puy de Dôme Station (France), Aerosol and Air Quality Research, 16, 909-917, 10.4209/aaqr.2015.05.0342, 2016.

Deguillaume, L., Charbouillot, T., Joly, M., Vaïtilingom, M., Parazols, M., Marinoni, A., Amato, P., Delort, A. M., Vinatier, V., Flossmann, A., Chaumerliac, N., Pichon, J. M., Houdier, S., Laj, P., Sellegri, K., Colomb, A., Brigante, M., and Mailhot, G.: Classification of clouds sampled at the puy de Dôme (France) based on $10 \mathrm{yr}$ of monitoring of their physicochemical properties, Atmospheric Chemistry and Physics, 14, 1485-1506, 10.5194/acp-14-1485-2014, 2014.

Ervens, B., Wang, Y., Eagar, J., Leaitch, W. R., Macdonald, A. M., Valsaraj, K. T., and Herckes, P.: Dissolved organic carbon (DOC) and select aldehydes in cloud and fog water: the role of the aqueous phase in impacting trace gas budgets, Atmospheric Chemistry and Physics, 13, 5117-5135, 10.5194/acp-13-5117-2013, 2013.

Ip, H. S. S., Huang, X. H. H., and Yu, J. Z.: Effective Henry's law constants of glyoxal, glyoxylic acid, and glycolic acid, Geophysical Research Letters, 36, 10.1029/2008g1036212, 2009.

Sander, R.: Compilation of Henry's law constants (version 4.0) for water as solvent, Atmospheric Chemistry and Physics, 15, 4399-4981, 10.5194/acp-15-4399-2015, 2015.

Sun, X., Wang, Y., Li, H., Yang, X., Sun, L., Wang, X., Wang, T., and Wang, W.: Organic acids in cloud water and rainwater at a mountain site in acid rain areas of South China, Environmental science and pollution research international, 23, 9529-9539, 10.1007/s11356-016-6038-1, 2016.

van Pinxteren, D., Plewka, A., Hofmann, D., Müller, K., Kramberger, H., Svrcina, B., Bächmann, K., Jaeschke, W., Mertes, S., Collett, J. L., and Herrmann, H.: Schmücke hill cap cloud and valley stations aerosol characterisation during FEBUKO (II): Organic compounds, Atmospheric Environment, 39, 4305-4320, 10.1016/j.atmosenv.2005.02.014, 2005.

Zhou, X., and Mopper, K.: Apparent partition coefficients of 15 carbonyl compounds between air and seawater and between air and freshwater; implications for air-sea exchange, Environmental Science \& Technology, 24, 1864-1869, 10.1021/es00082a013, 1990. 